\title{
Universiteit
}

Leiden

The Netherlands

\section{Styles of Legislation and their effects}

Voermans, W.J.M.

\section{Citation}

Voermans, W. J. M. (2011). Styles of Legislation and their effects.

Statute Law Review, 32(1), 38-53. doi:10.1093/slr/hmq013

Version: $\quad$ Not Applicable (or Unknown)

License: $\quad$ Leiden University Non-exclusive license

Downloaded from: https://hdl.handle.net/1887/16566

Note: To cite this publication please use the final published version (if applicable). 


\title{
Styles of Legislation and Their Effects*
}

\author{
WIM VOERMANS ${ }^{+}$
}

In matters of grave importance, style, not sincerity, is the vital thing-Oscar Wilde $^{1}$

\section{Does Style Matter?}

Until recently, matters of legislative style were not often given serious consideration in legal scholarship. First, because legislative style was not perceived as a matter of consequence; secondly, because style was seen as a question of taste, and thus not very well suited as a subject of objective research; and thirdly because legislation itself has generally been little studied by academics. ${ }^{2}$ Such limited academic consideration of the style of legislation as there has been is largely prescriptive in approach. It mainly makes the case for clear, precise, and simple drafting in order to improve the accessibility, readability, and comprehensibility

+ Professor of Constitutional Law, Leiden University, Leiden, The Netherlands; Dean of the European Academy of Law and Legislation; a vice-president of the International Association of Legislation

* The article is a synthesis of, and commentary on, papers presented by invited contributors to a conference on 'Styles of Legislation' held on the occasion of the opening of the European Academy for Law and Legislation, at the Peace Palace, in the Hague, 17-18 December 2009. The author is very grateful to the following for permission to draw on their papers to the conference: Mr. Edward Donelan, Dr. Helen Xanthaki, Professor St. John Bates, Professor Dr. Luzius Mader, H. E. Dr. E. M. H. Hirsch Ballin, Professor Dr. Patricia Popelier, Dr. David Keyearts, Mr. Benoit D. Turcotte, Professor Dr. Ulrich Karpen, Professor Dr. J.-P. Duprat, Dr. Rob Visser and Professor Dr. L. Wintgens. The papers were summarized by the conference organizers and the summaries approved by the authors, and it was that summary which largely underpins this article. Although the conference organizers considered that this would make the deliberations more readily accessible than publishing a verbatim transcript of the proceedings, individual contributors may also choose to publish elsewhere and in various forms their conference papers or extended versions of them.

1 The Importance of Being Earnest (1895), Act III.

2 RW Bauman and T Kahana The Least Examined Branch. The Role of Legislatures in the Constitutional State (Cambridge University Press Cambridge 2006) 15-32. 
of legislation or law-related documents ${ }^{3}$ or, on similar reasoning, advocates law reform by using plain language. ${ }^{4}$

Yet the style of legislation does matter and is therefore worthwhile studying both from an academic point of view as well for practical purposes. Legislation in itself is a style, the form in which we cast public interventions. In order to underline their importance, we wrap decisions like these in a ceremonious packing to indicate that the proper procedure was followed and that, by force of its style, it can rightly be deemed law. So legislation is, first of all, a channel of symbolic communication. ${ }^{5}$ We read more out of legislation than we would from an ordinary text. Legislation denotes a level of agreement, authority, command and obligation to comply, force of law, and-at least the expectation of-expression of principles of justice. Or, as Gibbon, notes:

Laws are coded in language, and the processes of the law are mediated through language. The legal system puts into action a society's beliefs and values ....6

The way legislation, as a vehicle of symbolic communication, voices the message (the style of legislation), therefore, obviously matters. The medium of legislation is in part the message itself. Admittedly, we know little about the way in which the form or style of legislation affects the outcomes of legislation, such as compliance or level of legitimacy. Conventional wisdom suggests that badly drafted legislation hampers understanding and interpretation and thereby compliance. We more or less know that large volumes of legislation, or over-detailed legislation, tend to create an administrative burden. ${ }^{7}$ And we know that just the form and style of legislation triggers compliant behavior from the bulk of its addressees, even if they do not know the penalty for non-compliant behavior. ${ }^{8}$

3 GC Thornton Legislative Drafting (4th edn Butterworths London 1996). RC Wydick Plain English for Lawyers (5th edn Carolina Academic Press, Durham North Carolina 2005).

4 See Wydick, above n 3 . J Barnes "The Continuing Debate About "Plain Language" Legislation: A Law Reform Conundrum' (2006) 27 Statute Law Review 83-132. M Cutts How to Make Laws Easier to Read and Understand. Paper delivered at the 'Laws for Citizens' Nordic-Baltic conference organized by the Swedish justice ministry in June 2008, to be retrieved at http:/ /www.clearest.co.uk/? $\mathrm{id}=34$. The plain language commission is on a mission to improve the readability of legal texts. The Commission has a website and issues a newsletter ('Pikesttaff'). http://www.clearest.co.uk/?id=1 last visited on 12 March 2010.

5 See WJ Witteveen and BMJ van Klink 'Why Is Soft Law Really Law?: A Communicative Approach to Legislation' (1999) 3 RegelMaat, Journal for Legislative Studies 126-40 . P Eijlander and W Voermans 'Outlooks for Legislation' (1999) 3 RegelMaat, Journal for Legislative Studies 120-5 .

6 J Gibbons 'Language and the Law' (1999) 19 Annual Review of Applied Linguistics 156-73.

7 WJM Voermans, C Moll, N Florijn and P Lochem 'Codification and Consolidation in the European Union: A Means to Untie Red Tape' (2008) 29 Statute Law Review 65-81.

8 BMJ van Klink De wet als symbool: Over wettelijke communicatie en de Wet gelijke behandeling mannen en vrouwen bij de arbeid (Legislation as a symbol; on legislative communication and the Law on equal treatment of men and women in labor relations). PhD thesis (Tilburg University W.E.J. Tjeenk Willink Deventer 1998). HM Prinsen and RMM en Vossen 'Naleving en handhaving van regelgeving; Loont het de moeite? (Compliance and Enforcement of Regulation: Is It Worth While?)' (2003) 9 Justitiële Verkenningen. WJM Voermans 'Wetgeving als software voor menselijk handelen? (Legislation as Software for Human Behavior)' in L Loeber (ed) Wetgeving en ICT-toepassingen, (Legislation and ICT-Applications) preadviezen van de Vereniging voor wetgeving en wetgevingsbeleid (Contribution to 
There is still another reason to look into matters of the style of legislation. We live in a world where law flows from many sources-national and internationaleven private bodies sometimes engage in law making. This prompts crosscultural, legislative interaction as, increasingly, international legal norms need to be implemented in, and aligned with, domestic law. Differences in the structure and the use of language in legislation may impede the implementation or co-ordination efforts of domestic legislators. Citizens and businesses are also increasingly affected by cross-cultural legislative interaction. Due to the internationalization of commerce and the reduction of barriers to the free movement of goods, especially within in the European Union (EU), commerce is increasingly governed by 'law from abroad' - be it World Trade Organization or EU law implemented in their national system - or even by domestic legislation of other EU Member States (e.g. the consumer law of other Member States in the case of internet shopping).

A different style of legislation than that with which you are familiar can impede ready access to the text of the legislation and thus its comprehension, even where it is translated into your domestic language. ${ }^{9}$ It may compromise the integrity and coherence of national bodies of law. The intensity of cross-cultural legislative interaction and subsequent transfer of ideas-and interdependencies resulting from it-therefore make insight into the styles of legislation of other countries rewarding. ${ }^{10}$ Increased insight into the legislative styles of others may prove to be an attribute during negotiations on international or EU legislation or decisions. It may also be helpful in their interpretation and domestic implementation.

Style matters for yet a further reason. We know that complex verbose legislation, full of jargon and legal constructs, not only complicates comprehension and interpretation but also irritates its audience and may otherwise tend to undermine its authority. Such complexity of style creates an additional burden by an increased need for legal and administrative explanation. Over-detailed legislation, employing unnecessary specialist language, is thus commonly expensive to

the Annual Conference of the Dutch Association for Legislation) (Weka Den Haag 2005) 105-10. Prinsen and Vossen found, when evaluating the Dutch Law on pollution control of surface waters, a compliance ratio of $74 \%$ against a portion of $26 \%$ offenders. Of the $26 \%$, only $9 \%$ were deliberate contraveners. The majority of the offenders did not know they were trespassing, as roughly $15 \%$ of the compliers did not know they were acting according to the law. For the majority of the compliers (53\%), sanctions were no motive for compliant behavior. Twenty-one per cent admitted to comply with the law because of the penalties pending trespasss.

9 O Lando 'On Legislative Style and Structure' (2006) 11 Juridica International 13-19. The EC Services Directive (2006/123/EC), for instance, gives providers and recipients of services in the EU a right to information on requirements on services in domestic legislation. On the basis of Art 7, the Directive Member States need to arrange for a point of single contact and to accommodate information on request by providing it in intelligible and plain language (even to foreigners).

10 CC EMH Hirsch Ballin Do Other People's Tools Only Work in Other People's Gardens? (the Conference opening keynote speech) (2009). "CC" followed by a named author, refers to a contribution to the inaugural European Academy for Legislation conference in 2009; the authors and the titles of their papers are listed in an annex to this article. 
use. There are, in other words, external effects of the style of legislation beyond merely issues of the level of access to the text and the capacity to comprehend it.

Last but not least, studying the style of legislation is valuable because we live in what one might call bench mark societies. Legal concepts and constructs shown to work well in one jurisdiction are now eagerly and rapidly adopted elsewhere; impact assessment of legislation, strategies that enhance compliance with legislation or reduce bureaucracy in applying legislation may all be cited as examples of this phenomenon. The process is aided by the law and practice of individual jurisdictions being made readily available by organizations such as the United Nation, Organisation for Economic Co-operation and Development (OECD), and the EU and also often by the jurisdictions themselves in publishing translations of their legislation and related official documents in widely read languages such as English and French. Not only does this facilitate the wider use of proven legal concepts and procedures but it also commonly allows one jurisdiction to compare its style of legislation with that of others and learn from the comparison.

\section{What Do We Mean by Style?}

Until now, we have not really defined the evocative term 'style'. Most people have an implicit notion of what 'style' is, but for the purposes of this article we must at least identify its principle aspects. If we discuss legislative style, we look at the way legislation is drafted. So style concerns the wording (general use of language, definitions, terminology, etc.), structure (its divisions, ways of referencing, etc.), and superstructure (its ways of presenting its relation to and the hierarchy between it and other legislative texts, etc.) of the legislative text, as well as its legal-cultural identity (within its own legal system and how that system is influenced by its origins, for example in the civil or common law tradition).

Defining legislative style in this way reveals that legislative style constitutes a set of legislative features that are highly dependent on the language, culture, both legal and political, of a society. So much so that it begs the question whether one can learn from, let alone compare, legislative styles. ${ }^{11}$ It would be something like trying to compare or translate proverbs. One could argue that they are part of the fabric of a nation's culture and cannot be studied or understood in isolation. Many of them are in fact not easily translated in a meaningful way and thus difficult to compare with proverbs in other languages and cultures. This may be true of the individual proverbs, but arguably there is still something to be learned on a meta-level. Even from foreign proverbs other cultures and systems may learn something. There is, for example, a Dutch saying which in literal translation is: 'If you do not shoot, you will always miss'. ${ }^{12}$ This does not translate well

11 Ibid., HE Hirsch Ballin, Dutch Minister of Justice, raised this question in his opening address 'Styles of legislation' European Academy for Law and Legislation.

12 In Dutch: 'niet geschoten, is altijd mis'. 
into English, ${ }^{13}$ and perhaps the closest English equivalent-'nothing ventured, nothing gained'-lacks the immediacy of the Dutch. Yet there may be value in knowing the Dutch saying. Its immediacy makes it readily understood and therefore quotable. And at a more dynamic level, quoting it, even in translation, may bring a smile to Dutch faces (and perhaps make them somewhat more amenable) in international meetings. So, exact comparisons may not always be possible but they are nonetheless instructive.

\section{Comparing Styles of Legislation}

The underlying purpose of the 2009 conference of the European Academy for Law and Legislation ${ }^{14}$ was to compare the distinctive and differing styles of national legislation and their effects when confronted with non-domestic law, such as treaties, EU legislation or the domestic legislation of other states. The structure of the conference was to ask invited contributors to comment on this from the perspective of some of the distinctive legislative styles within their own jurisdictions, followed in each case by general discussion. Many of the contributors were from EU Member States. There we know, for instance, that domestic legislative style impacts on the domestic implementation of EU legislation, ${ }^{15}$ but were there other effects of style? In addition, a broader perspective was provided by invited contributions from Mr. Bevis Clark-Smith, the Director of the Directorate for Quality of Legislation in the European Commission Legal Service (who considered the matter from an EU perspective), and from Professor Luzius Mader and Mr. Ben Turcotte from, respectively, Switzerland and Canada, who analyzed the particular stylistic demands of legislating multilingually, demands which also of course face the EU.

\section{Comparative Analysis}

As already indicated, legislative style may be said to consist of three broad aspects components: wording and phraseology, structure, and features relating to the legal-cultural identity of legislation. These are now considered individually.

\section{(A) Legislative Style-Wording}

According to Gibbons - an American scholar in applied linguistics-law is language. 'It is not solely language, since it is a social institution manifested also in

13 In English translation, the rhythm and succinctness of the original is somewhat lost.

14 The European Academy for Law and Legislation is a Dutch initiative which aims to create a community of legislative professionals with a common frame of reference. The Academy offers training courses and information services. http:/ /www.eal.eu/index.php/en/eall-about.

15 B Steunenberg and W Voermans The Transposition of EC Directives: A Comparative Study of Instruments, Techniques and Processes in Six EU Member States (Leiden University/WODC Leiden 2006). 
non-linguistic ways, but it is a profoundly linguistic institution. Laws are coded in language, and the processes of the law are mediated through language. The legal system puts into action a society's beliefs and values, and it permeates many areas of life . . . ${ }^{16}$ In his view, legal communication includes non-verbal semiotic systems (gestures, illustrations, etc.) as well as a linguistic system with a least three levels: the grapho-phonic system (e.g. the font used in a legal document, the pace and intonation of a judges' instruction to a jury, etc.), the lexicogrammatical system (words, morphology, syntax, etc.), and the discourse system, including genres. ${ }^{17}$

When drafting legislation, civil servants and political actors, typically focus on the lexicon-grammatical element, and possibly overemphasize the power to communicate the law only by means of words on paper. Legislative actors are accustomed to negotiate over words and are not prone to experiment with other means of communication. Bates ${ }^{18}$ addressed the theme of 'drafting by more than words' in his presentation. Words, in his view, have intrinsic limits where it comes down to conveying legal messages: words occasionally have 'blurred' edges, can be ambiguous and need to be interpreted (which may turn out to give a different result than originally intended). ${ }^{19}$ Typography and graphics can sometimes be more helpful in transmitting meaning than words are. Even when using words, the way they are presented and placed (using alphabetical labels, lists, boldface and italics to indicate repeals or insertions, etc.) do matter for the overall accessibility. National legislatures are not very innovative in this respect. The way amending legislation is set up in different countries within the EU resists access to it. Amendments most of the time are complex instructions to the authority or official publisher who has to consolidate the amendment after enactment. More is possible here, as the EU example shows, where different fonts are used in draft amendments to indicate whether a piece of text is repealed or inserted.

\section{(i) Wording and Multilingualism: Methods and Strategies}

The wording of legislation is especially difficult when more than one language is involved to carry the legislator's message. The EU is a showcase here. The EU is a Union of many languages and these languages are commonly domestically perceived as bulwarks of national identity. Hence, language and multilingualism is a big issue in the EU. It is no surprise that the first ever Regulation of the European Economic Community was on languages. ${ }^{20}$ There are 23 official languages as of 1 January 2007 which makes for the drafting of EU documents challenging. Clear, simple, and precise drafting — the quality goal the Union has set itself-is

16 See Gibbons, above n 6.

17 Ibid., 156

18 CC St. J Bates 'Drafting by More Than Words' (2009), an expanded version of the paper has been published in [2010] 36 Commonwealth Law Bulletin107.

19 S Simison and D Whelan 'Courts Leave Bad Drafting Out in Cold' (2003) Mondaq Business Briefing.

20 Regulation no. 1 determining the languages to be used by the European Economic Community OJ L 17, 6 October 1958, 385. 
even made more difficult because of the dynamics of the EU legislative process. Most drafting is the result of complex political compromises which leave their marks on the texts. Constructive ambiguity greases the wheels of political cooperation, but makes for difficult reading and interpretation. There are no easy general solutions to the conundrums multilingualism, although the EU Joint Practical Guide offers detailed specific guidance on the matter. ${ }^{21}$ The problem lies not only with the translatability of the language itself used $^{22}$ but also in the different and distinctive legal concepts deployed. For instance, the concept of 'faute' in French Law has no direct equivalent in other legal systems. In order to meet the challenges of parallel drafting in so many languages, the EU employs specialized staff in its translating services (all of the three institutions involved in the legislative process have one), which eclipse the other services in sheer size. ${ }^{23}$ For the legal aspects of drafts 'legal revisers' review texts and check that the correct legal terminology is used and the legal implications are the same in each official language. Again, all three 'legislative' institutions have legal revisers. The complexities of multilingual drafting present themselves not only during the drafting stages but also during the phases of transposition, implementation and the interpretation. EU directives have to be transposed into national legal orders that differ considerably. In different countries, there have been debates on whether it is better to ensure a close fit of the Directive and national law and hence integrate the provisions of a Directive as much as possible into national law (often called elaboration) or try to do no more than is precisely required by the terms of the Directive. Recently, both in the UK and the Netherlands, the latter method has come to be preferred because on the whole this approach results in less of an administrative burden on citizens and economic actors. ${ }^{24}$ Transposition and implementation may also be more difficult as a consequence by domestic constitutional structures. Popelier and Keyaerts point to this in the context of transposing and implementing directives in Belgium. Belgium, being a federal state, sometimes makes centralized transposition under the federal division of power difficult, and it is made more difficult by its multilingualism. ${ }^{25}$ This requires carefully managed co-ordination of inputs and strict planning of the transposition efforts. For this purpose, Flanders has come up with an 'Implementation of EC Directive Scheme'.

21 Joint Practical Guide of the European Parliament, the Council and the Commission; for persons involved in the drafting of legislation within the Community Institutions, Brussels 2000. Especially its point 5 .

22 This on its own is difficult enough. Twenty-three language versions with the same authenticity and authority make language-neutral writing the only possible solution. The Joint Practical Guide warns against language specificity in texts. See Joint Practical Guide, point 5.

23 Clarke Smith, Bevis (2009), Better Regulation in the EU: the Commission's perspective.

24 Davidson Review Implementation of EC Legislation (Final report) (Cabinet Office London 2006); Cabinet Office Transposition Guide: How to Implement European Directives Effectively (Cabinet Office London 2005) (revised in 2007); WJM Voermans 'Concern About the Quality of EU Legislation: What Kind of Problem, by What Kind of Standards?' (2009) 2 Erasmus Law Review 59-95.

25 CC P Popelier and D Keyaerts Taking EC Directives Seriously? The Belgian Style (2009). 
Multilingualism in the EU also impacts on the interpretation of law, especially that of the courts. EU courts co-ordinate their efforts and interpretation of EU law via a system of decentralized co-ordination and central adjudication (preliminary ruling proceedings and appeals). The way the European Court of Justice (ECJ) approaches interpretation of EU law of course is critical in this system. According to Jacobs, the ECJ's approach to interpretation has been consistent over the years. It is ideological, taking account of the purpose of the legislation, and it is contextual, taking account of the scheme of the legislation and its place in the framework constituted by the Treaties and European law in general. ${ }^{26}$ The ECJ therefore sometimes considers the travaux préparatoires, such as the Commission proposal and the explanatory memorandum. On the basis of those elements, the ECJ may be ready to depart from clear wording more than certain national courts. Due to the politicized nature of the European legislation, texts may show a lack of clarity or ambiguity, which makes them difficult to interpret. That is part of the reason why the ECJ over the years has emphasized a purposive approach. In case of multilingual complexities, the ECJ draws inspiration from Article 33 of the Vienna Convention: if comparison of different language versions reveals differences, the interpretation should be chosen which best reconciles the text and the purpose. ${ }^{27}$

\section{(ii) Multilingualism and Legislation outside the EU}

There are other multilingual jurisdictions in the world whose experience is of great value not only for the EU but also more generally as jurisdictions that are faced which increasing volumes of supranational and international law. Canada, for instance, is a federation with bilingual legislation. The country is famous for its co-drafting, a method by which each bill is drafted in parallel by two lawyers, one anglophonic and the other francophonic. This means that texts do not need to be translated, which reduces potential difficulties ${ }^{28}$ and operates better in a context of bijuralism. Federal legislation in Canada is bijural in nature because it applies in the civil law province of Quebec as well as in the other common law provinces. Federal legislation therefore needs to be adaptable to both legal systems. ${ }^{29}$ Bilingual drafting in a bijural context is no mean feat. To overcome some of the complications the Canadians have resorted to two harmonization Acts-ironing out divergences between federal law and provincial law-which have been adopted by Parliament. ${ }^{30}$

26 F Jacobs How to Interpret Legislation Which Is Equally Authentic in Twenty Languages?, Lecture, Brussels, 20 October 2003, seminars on quality of legislation organized by the European Commission (see http:/ /ec.europa.eu/dgs/legal_service/seminars/agjacobs_summary.pdf).

27 Ibid.

28 MJB Wood 'Drafting Bilingual Legislation in Canada: Examples of Beneficial Cross-Pollination between the Two Language Versions' (1996) 17 Statute Law Review 66-77.

29 CC BD Turcotte Canadian Federal Legislation in a Bijural Context (2009).

30 The Federal Law-Civil Law Harmonization Act, No. 1, S.C. 2001, c. 4 and the Federal Law-Civil Law Harmonization Act, No. 2, S.C. 2004, c. 25. 
Such co-drafting can result in different versions of the same piece of federal legislation, unlike for instance the Swiss system. ${ }^{31}$ In Switzerland, quadrilingualism is an element of Swiss national identity enshrined in the Constitution. ${ }^{32}$ This has long been the case and as a result the Swiss have a lot of experience of multilingual drafting. ${ }^{33}$ Although the Swiss, unlike the Canadians usually do not co-draft as such (most of the time a proposal is drafted in one language only-commonly in German), ${ }^{34}$ the Swiss use an intermediate stage of revision and text control once a draft has been drawn up and translated. ${ }^{35}$ To ensure that all texts are equivalent, coherent and precise, and meet with relevant 'good legislation' requirements, they are scrutinized by text revision committees within the executive. These committees also ensure that all language versions of a draft are of identical legal content. ${ }^{36}$ Another typical Swiss language feature is the language opt-in. The Languages Act gives citizens a choice of language for communication with the government (Article 6 (1)). This reflects Article 70 of the Swiss Constitution which provides that the official languages of the confederation are German, French, and Italian and that Romanesh is also an official language for communications with persons who speak that language. ${ }^{37}$ The concept of the latter 'relative' official language is an interesting one for the EU which is grappling with its flood of official languages.

Ireland too has a constitutional provision on official languages. Under Article 8 of the Irish Constitution, Irish is the official language of Ireland and English the second official language. Legislation, however, more often is drafted in English and then translated into English. ${ }^{38}$ From his own extensive experience as a legislative drafter in Ireland, Mr. Donelan observed that there are no formal institutional links between the drafters and the translators of legislation in Ireland, and he considers that the intelligibility of the legislation would be enhanced by closer links between the translation service and legislative drafters during the drafting process. ${ }^{39}$

\section{(iii) 'Plain Language' Drafting}

In recent decades, there has been an increasing emphasis on drafting in 'plain language'. ${ }^{40}$ This has been a reaction to the often complex, detailed, and technical language often used in legislative drafting, particularly in common law jurisdictions. Such language, which counter-intuitively can often detract from legal

31 A Lötscher 'Multilingual Law Drafting in Switzerland' in G Grewendorf and M Rathert (eds) Formal Linguistics and Law (Mouton de Gruyter Berlin 2009), 386.

32 CC L Mader Multilingualism and other distinctive aspects of Swiss legislation (2009).

33 See Lötscher, above $\mathrm{n} 31$.

34 Long texts are sometimes drafted using different languages in different parts.

35 See CC Mader, above n 32.

36 See Lötscher, above n 31, 384.

37 See CC Mader, above n 32.

38 CC E Donelan Accessibility of Legislation: Opportunities and Challenges (2009).

39 Ibid.

40 See "http://en.wikipedia.org/wiki/Plain_Language_Movement."; E Hondius Sense and Nonsense in the Law; towards Clarity and Plain Meaning. Inaugural address delivered on 28 November 2007 while accepting the Faculty Chair in European Private Law, University of Utrecht (Kluwer Deventer 2007). "http://igitur-archive.library.uu.nl/law/2008-0114-201437/hondius_07_senseandnonsenseinthelaw.pdf. 
precision, is also increasingly recognized as obstructing comprehensibility and adding to the expense of implementation. Two relatively recent official initiatives, amongst others, ${ }^{41}$ may be particularly mentioned.

In Scotland, some administrations have tried to tackle this problem by training their staff in plain language skills and setting up manuals with directives and best practices. According to the Scottish Plain Language and Legislation booklet, ${ }^{42}$ plain language is:

direct and straightforward. It is designed to deliver its message to its intended readers clearly, effectively and without fuss. Writing in plain language involves doing more than simply using intelligible words and expressions. Good grammar is needed for any written text to be readily understood. Organising material logically and structuring sentences simply allows information to be absorbed more easily. Designing a simple physical layout makes a document easier to read.

In 2000, the Irish Law Reform Commission recommended a comprehensive programme of reform of Irish law be undertaken, with a view to replacing existing statutory provisions with alternatives expressed in plain language. The report encourages the use of familiar and contemporary language and shorter and less elaborate sentences but recognizes that:

this aim should not be achieved at the expense of legal certainty. ${ }^{43}$

This last element is a permanent challenge for those advocating plain language in legislative drafting. It has proven particularly difficult to translate existing legislation (e.g. the Toy-Safety Directive 88/378/EEC) into a legally equivalent plain language version. ${ }^{44}$

\section{(B) Legislative Style-Structure and Accessibility}

The structure of an Act can act as a road map for users who want to find the relevant provisions. A well-conceived structure leads the user to the place of interest and, therefore, is important for the overall accessibility of an act. It may also contribute to the meaning of specific norms (the context of a chapter or a section can

41 See, for example, 'drafting guidance' (part 1) published by the (UK) Office of Parliamentary Counsel, and its references to similar material in other (British) Commonwealth jurisdictions: "http://www.cabinetoffice.gov.uk/parliamentarycounsel/drafting_technique.aspx".The European Commission also uses a manual for English documents of its own. See Directorate-General for Translations of the European Commission (Fight the Fog) How to Write Clearly. Brussels (no year of publication provided). http://www.au.af.mil/au/awc/awcgate/eu/fight_the_fog_en.pdf.

42 Scottish Plain Language and Legislation Booklet (2006), http://www.scotland.gov.uk/ Publications/2006/02/17093804/0.

43 Irish Law Reform Commission Statutory Drafting and Interpretation: Plain Language and the Law (2000) (LRC 61-2000).

44 E Tanner 'Clear, Simple, and Precise Legislative Drafting: How Does a European Community Directive Fare?' (2006) 27 Statute Law Review 150-75. 
give a specific meaning to an article-rubrica est lex) and structure may be used to avoid unnecessary repetition. It is typical for the style of most legislation in European countries to structure legislation using paper-based, written labels. The text of legislation is predominantly structured as one would structure a book. Text organized in lines (not columns) running from top to bottom divided into parts, chapters, sections, etc. ${ }^{45}$ During the conference, Professor Bates made the point that the structure of acts may benefit from alphabetic labels or mathematical labels. Traditionally, we sometimes use abbreviations to avoid repetition. For instance (in an explicit definition):

OFCOM means the Office of Communications as established by the Office Communications Acts.

Or (in a running definition):

This section applies where a penalty notice has been given to a person ('the employer') under section 22 by a local education authority.

Bates argues that one could take this idea one step further by using singlelettered alphabetical labels in cases where numerous classes are affected in different ways, and such labels would avoid verbose repetition. The use of single alphabetical labels may simplify and clarify the text. This was an interesting example given by Bates:

(1) This section applies where an application is made to a magistrates' court under (...) in respect of a person $\left({ }^{\prime} \mathrm{P}^{\prime}\right)$.

(2) After the hearing-

(a) the applicant, and

(b) $\mathrm{P}$, if $\mathrm{P}$ wishes to be heard,

the court may make a violent offender order in respect of $\mathrm{P}$ if it is satisfied that the conditions in subsection (3) are met.

(3) The conditions are-

(a) that $P$ is a qualified offender, and

(b) that P has (. . .) acted in such a way as to make it necessary to make a violent offender order for the purpose of protecting the public from the risk of serious violent harm caused by $\mathrm{P}$.

Admittedly, it takes some getting used to, but when we add the possibilities of word processing and presentation present day information technology offers to the equation, it opens new possibilities to present texts in ways that may dramatically improve the overall accessibility of legislation. ${ }^{46}$ If $\mathrm{P}$ for instance is a (clickable) tag

45 See CC Bates, above n 18.

46 G Sartor 'Open Management of Legislative Documents' in C Stefanou and H Xanthaki (eds) Drafting Legislation; A Modern Approach (Farnham, Surrey Ashgate 2008) 259-85. 
in an electronic text, it is easier to get the message of the text in a glance, rather than get lost in a mishmash of words. ${ }^{47}$ This way of text presentation may also make explicit the logic of a provision, not only making it easier to understand but also, on occasion, improve it by exposing its flaws. Such a presentation would also, by its emphasis on the underlying logic of a provision, facilitate its presentation, for instance by using artificial intelligence techniques. ${ }^{48}$

Accessibility of legislation amounts to more that just the readability and comprehensibility of the legislative text. The overall accessibility of legislation is also determined by the way it is formally and informally communicated (promulgation, publication, public relations, press releases, etc.) and the manner in which the legislative text may be accessed. Accessibility is vital to the credibility of legal and political systems that operate on the presumption that everybody is supposed the law. ${ }^{49}$ Credibility, in turn, creates stability, trust, and confidence and may thus enhance economic performance. For an investor, it will be important to know the law (in another country) before deciding upon an investment. Accessibility is important on another plane as well: if the process and outcome of legislation are transparent then the relevant documents should be easier to access.

For these reasons, states have increasingly in recent years developed policies to improve the accessibility of their legislation, often in response to OECD initiatives. Electronic databases, codification (enacting legislation as a comprehensive logical presentation of the substance of earlier legislation, while repealing its obsolete provisions, and adding any necessary new provisions), and consolidation (usually a more limited legislative exercise of re-enacting existing legislation, inserting the amendments which have been made to it, and only including new provisions which are necessary to achieve an effective re-enactment) have been used as the tools of choice. ${ }^{50}$ The EU has made codification and consolidation of legislation a cornerstone of its legislative simplification programme during the first Barosso Commission's term, on the basis that this reduces the administrative burden of the legislation. ${ }^{51}$

Many EU Member States seem to have followed suit. Donelan observes a convergence in European countries as regards best practices on early consolidation on amendment of legislation (and reconsidering the format in which amendments are made), the organization of regular reviews of the stock of legislation against a set of regulatory reform principles (rolling programmes), the acceptance of electronic versions of legislation by courts as authentic acts, a more seamless IT-assisted, transparent process from the conception to the enactment, and eventual amendment of legislation. ${ }^{52}$

47 See CC Bates, above n 18.

48 E Francesconi and A Passerini 'Automatic Classification of Provisions in Legislative Texts' (2007) 15 Artificial Intelligence and Law 1, 1-17.

49 See CC Donelan, above n 38.

50 In the United Kingdom, consolidation is understood as 'codification' as it is defined here, and-vice versa-consolidation is labeled 'codification'.

51 See Voermans et al., above $n 7$.

52 See CC Donelan, above $\mathrm{n} 38$. 
Texts that are too long resist accessibility and comprehensibility. That is why drafters and framers of legislation try to avoid repetition in legislative texts. Techniques used for that are definitions and references. Making a reference in a legislative text to a concept or a part of another document (external reference), or to another place in the legislative text itself (internal reference) save words. On the other hand, too many such references make for very difficult reading. Most jurisdictions use rules of thumb to navigate the Scylla of repetition and the Charibdis of over-referencing.

In the inter-institutional agreement on the quality of drafting of Community legislation of 1998 (OJ C 73, 1-4) - a technical drafting manual used by the EU institutions - the EU has drawn on the experience of Member States ${ }^{53}$ in this respect. In its point 16 it advises (in conjunction with the Joint Practical Guide $2000^{54}$ ) the following:

References must be clear and should be made to another act only if:

- it makes it possible to simplify the text, by not repeating the content of the provision referred to;

- the comprehensibility of the provision is not affected; and

-the act referred to has been published or is sufficiently accessible to the public.

There is some more room to maneuver for internal references, but the principles of transparency and comprehensibility are key; it should be possible to read and understand a legislative act without excessive consultation of other legislation. Most countries adopt drafting principles to accommodate this.

For EU Member States (and applicant states too), referencing to EU legislation - particularly directives-adds a further dimension to this. In domestic law transposing or implementing EU legislation references, especially dynamic references (i.e., a reference to an act including all future amendments to that act) are abundant. Some countries resort to mere referencing as a means of transposition. ${ }^{55}$ Overzealous referencing makes it very difficult-as we have seen-to understand an act as it stands. Belgium uses drafting guidelines to overcome this problem. These guidelines require that domestic transposition acts mention the relevant EC directive (or when it concerns an implementation act the EU regulation or decision) in the enacting terms of the act itself. They furthermore require concordance tables (which directive provision is transposed into which provision or part of the transposition act) and that terminology should be in accordance as far as possible with the terms used in the Directive. ${ }^{56}$

53 Clarke Smith, Bevis (2009), Better Regulation in the EU: the Commission's perspective.

54 See above n 21, Joint Practical Guide 2000.

55 See Steunenberg and Voermans, above n 15.

56 The Dutch drafting directives require this too in its directive 56; see CC Popelier and Keyaerts, above $\mathrm{n} 25$. 


\section{(C) Legal-Cultural Identity}

An important style feature is the legal-cultural identity of legislation. This is a somewhat amorphous but important aspect of legislation. The legal-cultural identity is determined by the constitutional context, the nature of legal system in which the legislation is found, and also the origins of that system.

The constitutional context obviously has a strong influence on the style of legislation. Where a constitution reserves the regulation of substantial areas of policy to the legislature, this may well affect the nature of domestic legislation. It may, for instance, result in elaborate codes (as in France and the USA) or extensive use of legislative delegation (sometimes quite unrestricted, as in the Netherlands).

The origins of a legal system may also have a significant influence on legislative style. In the Western world and jurisdictions influenced by it, many legal systems law derive from the civil law or common law tradition. ${ }^{57}$ Traditionally, the primary feature of civil law is that laws are predominantly codified, and the code rather than individual judicial decision is dominant; in contrast to the common law which was largely developed by judicial decision. Although that is a rather simplistic contrast in the modern world, it is one that some feel still influences differences in approach to legislation and in consequence the style in which it is drafted. Lando for one feels that, for example, the elaborate, detailed style of the British legislation is explained by the common law origins of the English legal system. In Great Britain, according to his interpretation, most statutes were originally enacted to counteract some mischief created by the case law, and that is why the courts in turn were very adverse to enacted legislation. To their mind, it upset the 'lovely harmony of common law'. ${ }^{58}$ So, when English judges interpreted statutes, they applied them only to the precise situations which they unquestionably addressed, leading to a narrow and textual construction of legislation. In Germany - a civil law system-precision in legislation was driven by the desire to arrive at a coherent and consistent body of legislation on different levels in which expressions were applied universally for the same phenomenon, avoiding unnecessary repetition, and placing general rules and concepts before the more specific ones. ${ }^{59}$ French legislative tradition-underpinned by the civil law tradition as well-is moreover influenced by Portalis' approach who felt that it is the task of the legislator to lay down the general maxims of the law, to establish principles to determine their implications and not to go down into detailed regulation of all the issues that may arise in every matter. ${ }^{60}$

Xanthaki rejects the idea of such a divide between common law and civil law drafting and legislation. First of all, to her mind, there are no pure common law

57 Some, such as South Africa and Scotland, of course derive from a mix of both traditions.

58 See Lando, above n 9, 14.

59 Ibid.

60 J.-É.-M. Portalis (1800) Discours préliminaire au premier projet de Code civil. (l'An VIII). (reprint) (Voix de la cité Paris 1999), 18-19. 
and civil law systems anymore, if they ever existed in their pure form. And secondly common law systems and civil law systems are converging rapidly, amongst others, under the influence of the case law of 'shared' courts like the ECJ in Luxemburg and the European Court of Human Rights in Strasbourg and the increasing volume of shared law (i.e. international law, EU law, etc.). ${ }^{61}$ She demonstrates this by comparing rules of interpretation in common law and civil law systems (indeed these show a lot of parallel and seem to be converging) and the way stare decisis - a rule according to which inferior courts have to adhere to the ruling on legal principles of superior courts - is entering into civil law system (e.g. the effect the case law of the ECJ has for the courts in the Member States).

Legislative style may also be affected by its institutional drafting origin. Legislation is often hallmarked by the department or policy field it originates from. Legislation regulating a particular policy area may share, otherwise distinctive, characteristics of, for example, structure and its use of referencing, definitions, and phraseology. This may result in 'legislative silos' or-as Van Poelje labels the phenomenon-'legislative families' ${ }^{62}$ Van Poelje observes that the preparation of legislation by individual departments in isolation-as is the case in the Netherlands-serves to explain why laws do not mesh with each other, why illogical differences of procedure exist and what drives the sometimes unmanageable proliferation of regulations. A department that drafts legislation is inclined to be circumscribed by its 'own' existing legislation legislative styles.

There may be positives which flow from the 'legislative silo' effect; it tends to encourage stylistic consistency and the stability and accessibility of a corpus of legislation in the particular policy field. On the other hand, the existence of a 'legislative silo' often complicates interaction and integration between areas of legislation as well as the transposition of international and of EU law. EU policies domains are, for instance, parceled out differently than those in Member States and consequently legislation is organized differently. EU legislation stemming from one Directorate General within the Commission can affect various domestic policy domains in Member States and not fit well at all. This is a factor which impedes transposition. ${ }^{63}$

The Swiss government has established an interesting system to organize legislation in a way that improves its accessibility and bring the possible fragmentation of legislation due to 'legislative silo' side effects under control. Federal legislation is published in an official compilation. ${ }^{64}$ The compilation is a structured taxonomy of legislation and makes it easy to find and access Swiss legislation. The EU and the US (at federal level) also uses compilations in this way, but on a rather more informal basis.

61 H Xanthaki Legislative drafting styles: is there really a common versus a civil law divide? (2009).

62 SO van Poelje Coördinatie van het milieubeleid, Overheid en milieu, de groei van de beperkingen (Coordination of Environmental Policy: Government and the Environment, Restrictions of the Growth) (Het Wereldvenster Baarn 1974) 65.

63 See Steunenberg and Voermans, above n 15.

64 See CC Mader, above n 32. 


\section{In Conclusion: Effects of Differences and Similarities in Legislative Styles}

One of psychiatrist Scott Peck's famous aphorisms is that we should share our similarities and celebrate our differences. It is an approach which might be adopted for comparing legislative styles. In a world were jurisdictions are drawing nearer under the influence of globalization and the subsequent rise of international and transnational law, domestic legislation and its distinctive features are no longer isolated and difficult access. Domestic law is not only affected by international and transnational law that needs to be implemented but also affected by the sheer knowledge of examples and practices in other jurisdictions. From our comparison of styles of legislation, we learnt that differences in legislative styles - be it domestically as a side effect of a 'legislative silo' or in transnational-domestic relations-present challenges in the field of co-ordination of legislation as well as challenges in ensuring a domestic law fit when transnational or international law requires domestic implementation or transposition. National differences in approaching these tasks, including those grounded in legislative style, are generally informative. Good practice in one jurisdiction can be adapted for use in another, and functionality is ultimately the litmus test for this. The differences in legislative style in formatting, accessibility, transparency, and life cycle management (including stock management) based on information technology, all point to potential best practice to achieve greater legislative effectiveness. Awareness of differences in legislative style is important on another plane, as it may give an edge in international or EU negotiations on draft legislation. Good antennae are an asset. ${ }^{65}$

Finally, differences are the most apparent feature when comparing legislative style but this may lead us to overlook the similarities. There are many of these too; for instance, similarities across jurisdictions in the broad structure of legislation, the use of drafting manuals, codification and consolidation practices, and referencing. Awareness of such similarities may well often be as important as an awareness of the differences and for the same reasons. 